Environment Conservation Journal 14(3)91-93, 2013

ISSN 0972-3099 (Print) 2278-5124 (Online)

Abstracted and Indexed

\title{
Studies on solid waste generation and composition in the institutional area of Akhnoor Town, Distt. Jammu
}

\author{
Shalini Sharma and Subash C. Gupta
}

Received: $22.08 .2012 \quad$ Revised: 12.11 .2012

Accepted: 20.01.2013

\begin{abstract}
The present paper deals with the analysis of solid waste generation and composition in the institutional area of Akhnoor town, within its municipal limits. For the purpose of studies, the institutional area was divided into four zones and from each zone, different institutions (viz. schools, banks, colleges and government offices) were selected for the sampling and analysis of solid waste for a period of one year. Methods of disposal of Municipal Solid Waste (MSW) alongwith characterization and management of solid waste were studied to assess its impact on the environment and people inhabiting the area.
\end{abstract}

Keyword: Solid waste, MSW, environment, disposal

\section{Introduction}

Man's frenzied approach of subjugating nature and natural resources, his anthropocentric worldview and lack of accountability for his self centered activities are the principal causal factors responsible for the deplorable environmental scenario. Man has lived for centuries in harmony with the nature and such symbolic relationship with the natural has shaped human development until the beginning of industrial era. It is the human invention in the natural process, particularly during the last few decades, which has created ecological destabilization and environmental problems of serious magnitude; problem of solid waste generation and disposal is one of them which is of grave concern to each one of us. Waste generation has acquired a danger status of being "Third Pollution" after air and water pollution with advancement in industrialization and population explosion, although it is not a new phenomenon. The amount of waste generated is increasing quantitatively as well as qualitatively and developed countries are contributing maximum towards it. Though a lot of work has been done on generation, composition and management of solid waste from India and abroad by various workers, but no work seems to have been done on solid

\section{Author's Address}

Department of environmental Science, University of Jammu, Jammu

Email: sharmashalini1977@gmail.com waste generated in the institutional area of Akhnoor Town. However, some workers like Rampal et al. (2002), Kour (2004), Rampal et al. (2002), Gupta et al. (2007), have provided some fragmentary information on the generation and characteristics of waste of Jammu Municipalities.

\section{Material and methods \\ Study Area}

The present study was conducted within the municipal limits of Akhnoor Town. Geographically, Akhnoor lies at a latitude of $32.9^{\circ}$ $\mathrm{N}$ and longitude $74.75^{\circ} \mathrm{E}$, situated in the NorthWest part of India and eastern part of Pakistan and is about $32 \mathrm{~km}$ from Jammu. It has a total area of 1.5 sq.km. with total thirty five different institutions.

\section{Methodology}

For the purpose of waste collection or sampling, the study area was divided into four different zones. From there four different zones, thirty five different institutions including 7 banks, 13 schools, 14 government offices and only one Government Degree College (GDC) were selected from the study area for the purpose of studies. The sampling was done over a period of one year i.e. from June, 2007 to May, 2008. The sampling of solid waste was done on monthly basis from each institution, 
segregated into different components and weighed separately with the help of spring balance.During each sampling, the total solid waste generated during the period of twenty four hours was collected and weighed.The qualitative and quantitative composition of solid waste were also calculated by analyzing the solid waste generated per day by each institution. The values of solid waste generation per school/college/ bank/ government office per day on monthly basis during one year study period were compiled to find out average solid waste per school/college/ bank/ government office per day generation with standard deviations.

\section{Results and Discussion}

Comparative study of average solid waste (kg/institution/month) generation at four different study zones, i.e. Zone-I to Zone-IV containing thirty five total institutions during one year has been made (Table-1). A critical evaluation of Table-1 has revealed that in the study area (i.e. Zone-I to Zone-IV), the total solid waste generated (kg/institution) during one year study period was estimated to be $166.188 \mathrm{~kg}$ with an average value of $13.85 \pm 0.458 \mathrm{~kg}$, out of which $144.61 \mathrm{~kg}$ $(87.01 \%)$ was contributed by biodegradable waste comprising of paperware, cardboard, clothware, jute, foliage, cotton, wood, food/garbage, etc. Nonbiodegradable waste was calculated to be 14.064 $(8.46 \%)$ constituting of plasticware, metalware, glassware, thermocoal, rubber, etc. and $7.524 \mathrm{~kg}$ $(4.53 \%)$ of inert waste comprising of hair, dust, pebbles, sand gravels etc. with average values of $12.05 \pm 0.397 \mathrm{~kg}, 1.172 \pm 0.044 \mathrm{~kg}$ and $0.327 \pm 0.016$ $\mathrm{kg}$, respectively. The results are in accordance with the findings of Rampal et al. (2002), Kour (2004) and Gupta et al. (2007) who also recorded highest percentage of biodegradable waste.The total waste generation during one year study period $\mathrm{kg} / \mathrm{institution/day} \mathrm{was} \mathrm{calculated} \mathrm{to} \mathrm{be} 0.455 \mathrm{~kg}$. With the record of total thirty five different institutions in Akhnoor town within municipal limits, the total waste generation was calculated to be 0.016 tonnes/day, 0.49 tonnes/month and 5.82 tonnes/year from the institutions of Akhnoor Town.

Table-1: Total average solid waste (kg/institution/month) generation and composition at study area (Institutional Area) for $1^{\text {st }}$ year, i.e., from June, 2007 to May 2008

\begin{tabular}{|c|c|c|c|c|c|c|c|}
\hline & Zone-I & Zone-II & Zone-III & Zone-IV & Total & \multicolumn{2}{|c|}{ Total } \\
\hline & A. $V$. & A. V. & A. V. & A. $V$. & A. V. & A. $V * 12$ & $\%$ \\
\hline $\begin{array}{l}\text { Biodegradable } \\
\text { solid waste }\end{array}$ & $6.55 \pm 0.223$ & $4.06 \pm 0.149$ & $32.00 \pm 1.059$ & $5.60 \pm 0.160$ & $12.05 \pm 0.397$ & 144.6 & 87.01 \\
\hline $\begin{array}{l}\text { Non- } \\
\text { biodegradable } \\
\text { solid waste }\end{array}$ & $1.26 \pm 0.056$ & $0.83 \pm 0.030$ & $1.99 \pm 0.064$ & $0.61 \pm 0.028$ & $1.172 \pm 0.044$ & 14.064 & 8.46 \\
\hline $\begin{array}{l}\text { Inert solid } \\
\text { waste }\end{array}$ & $0.70 \pm 0.020$ & $0.53 \pm 0.018$ & $0.93 \pm 0.018$ & $0.35 \pm 0.009$ & $0.327 \pm 0.016$ & 7.524 & 4.53 \\
\hline $\begin{array}{l}\text { Total solid } \\
\text { waste }\end{array}$ & $8.51 \pm 0.265$ & $5.42 \pm 0.181$ & $34.92 \pm 1.118$ & $6.56 \pm 0.182$ & $13.85 \pm 0.458$ & 166.188 & \\
\hline $\begin{array}{l}\text { Biodegradable wast } \\
\text { Non-biodegradable } \\
\text { Inert waste }\end{array}$ & & dust, $g$ & alinc & $\begin{array}{l}\text { are, thermoc } \\
\text { etc. }\end{array}$ & rubber, leath & zg shell/1/ & \\
\hline
\end{tabular}

When a comparative study of solid waste generated followed by Zone-I $(8.51 \pm 0.265 \mathrm{~kg})$, Zone-IV at all the four study zones in the institutional area $(6.56 \pm 0.182 \mathrm{~kg})$ and minimum in Zone-II was made, it was observed that the total average $(5.42 \pm 0.181 \mathrm{~kg})$ respectively. No set pattern of solid waste generated ( $\mathrm{kg} /$ institution/month) was waste generation was observed in the institutional found to be maximum in Zone-III $(34.92 \pm 1.118 \mathrm{~kg})$ area during one year study period. 


\section{Acknowledgements}

The authors are highly thankful to the Department of Environmental Sciences, University of Jammu, Jammu for providing necessary facilities to undertake the present investigations.

\section{References}

Gupta, Subash C. and S. Sambyal 2007. Solid Waste Management: A case of study of Samba Town of Jammu division of Jammu and Kashmir. Indian J. Conser. and Ecoplan, 14 (3): 571-574.

Kour, J. 2004. Generation, disposal and management of solid waste in Jammu city. Ph. D. Thesis, University of Jammu, Jammu.

Rampal, R. K. and D. Sharma 2002. Generation and disposal of solid waste at Bagh-e-Bahu complex of Jammu. Indian $\mathbf{J}$. Environ. and Ecoplan, 7 (1): 51-54. 